\title{
Comparative studies on the effect of some antioxidants on renal dysfunction in rats
}

\author{
Hewaida A.E.Fadel *; Essayed A. Hassanin *; Zakaria E. Rihan**; Eveleen S. Abd Allah *** \\ Department of Nutritional Chemistry\& Metabolism, National Nutrition `Institute*; Department of \\ Endocrinology, Military Medical academy**; Department of Home Economies, Ain Shams \\ Univerersity****.
}

\begin{abstract}
The present study is carrying out for investigating the effect of supplementation with some vitamins (A, E\&C) as natural antioxidant extracts in renal dysfunction in rates.

Material\& Methods: 40 adult male Sprague - Dawley rats $(150-200 \mathrm{~g})$ divided to two groups. First group: 8 rats were fed on standard diet (S.D.), as a control group. Second group: 32 rats were injected intraperitonial with a single dose of Cis-diammine dichloride Platinum II (CDDP) for inducing renal dysfunction $(2.5 \mathrm{mg} / \mathrm{Kg})$ then it was divided to six subgroups each one contained 8 rats. (1): fed on (S.D.) nephrotoxic group. (2): fed on (S.D.) + Vitamin A (15 mg/Kg body weight/day). (3): fed on (S.D.) + Vitamin E (317 I.U. /kg body weight/day). (4): fed on (S.D.) + Vitamin C (280 I.U. /kg body weight/day). The experimental period was four weeks, results were statistically analyzed.

Results: The results proved that groups of nephrotoxicity rats supplemented with Vitamin A,E and C showed significant increase in food intakes, body weight gain and food efficiency ratio (FER) $(28.9 \%, 29.4 \%$ and $19.2 \%),(870.5 \%, 1615.6 \%$ and $409.8 \%)$ and $(652.5 \%, 122502 \%$ and $327.3 \%)$ respectively, compared with nephrotoxic group. The nephrotoxicity rats supplemented with Vitamin A and showed significant reduction in serum vitamin E \& kidney glutathione content (9.3\% \& 47.9\%), while nephrotoxicity rats supplemented with Vitamin E\&C showed significant increase in serum vitamin E \&kidney glutathione content (27.9\% \& $116.6 \%$ ), $(13.7 \% \& 55.8 \%)$ respectively. The results showed that nephrotoxicity rats supplemented with Vitamin A,E and $\mathrm{C}$ showed significant reduction in serum urea nitrogen and creatinine $(48.01 \%$ and $55.2 \%),(52.6 \%$ and $60.3 \%)$ and $(57.0 \%$ and $63.04 \%)$ respectively. Best results in histopathological examination of kidney were in vitamin $\mathrm{A}$ and vitamin $\mathrm{C}$ groups.
\end{abstract}

Conclusion: These results suggest that natural antioxidants could be beneficial as additional therapy in renal dysfunction.

Key words: Natural antioxidants - Renal dysfunction - Nephrotoxicity - Histopathological examination Kidney function.

\section{Introduction}

The kidneys are the main organs of the body through which nitrogenous wastes are excrete in the form of urea (Shubhangini, 2001) .The basic functional unit of the kidneys is the nephron. Most kidney diseases attack the nephrons. Causing them to lose their filtering capacity. The two most common causes of kidney disease are diabetes and high blood pressure (Bruce, 2004). Any disorder in the kidney results in serious complication of the circulatory system, high blood pressure, anemia, weak bones, poor nutritional health, nerve damage and cause complications may not satisfactory consequences (Perazella, 2006). A world wide, the number of patients who receiving renal replacement

therapy is estimated at more than 1.4 million, with incidence growing by approximately $8 \%$ annually. At the year 2025 the kidney failure patients in the world will be 10 million, $70 \%$ of them are there in growing countries. In Egypt there are more than 120000 patients suffering from kidney failure. Driving this increase are population ageing, diabetes mellitus and hypertension, the key risk factors for chronic kidney disease (Sarah et al, 2008). The specialized researches confirmed that 
the last 10 years in Egypt have shown a significant increase in the number of children living with kidney failure between the ages of $2-10$ years and has become representing $15 \%$ of patients with kidney failure (Sarah et al, 2008). Various environmental agents such as (chemical pesticides, solvents and similar materials), animal venom, certain plants and some drugs are nephrotoxic by producing free radicals such as $(\mathrm{O} 2, \mathrm{RO} 2, \mathrm{OH}$, NO2, NO) which can cause kidney damage and dysfunction by starting chain reactions that damage cells (Staci Nix, 2005).

Antioxidants are molecules capable of slowing or preventing these chain reactions by removing free radicals intermediates and inhibit other oxidation reactions by being oxidize themselves (Bjelakovie, 2007). Moreover, Saravanan and Nalini, (2007) demonstrated that treatment with antioxidants offers protection against free radical-mediated oxidative stress in kidney of animals with nephrotoxicity. In addition, Mohamadin et al, (2005) indicated that oxidative stress plays a role in nephrotoxicity and renal dysfunction in rats. Supplementation with antioxidants could be useful in nephrotoxicity in rats.

Athinson et aI. (2007) mentioned that vitamin E is an essential nutrient that functions as an antioxidant in the human body. The body cannot manufacture its own vitamin $\mathrm{E}$ and thus it must be provided by foods and supplements. It is more appropriately described as an antioxidant than a vitamin. Pompella et al, (2003) mentioned that Glutathione has been called the "master antioxidant," in addition to its own potent antioxidant powers, glutathione helps to recycle other antioxidants such as vitamins $\mathrm{C}$ and $\mathrm{E}$. Thus, glutathione can help to protect against cancer and other diseases caused by oxidative damage. Glutathione also plays an important role in the regulation of immune cells, and is a potent detoxifying agent. Low levels of glutathione have been associated with hepatic dysfunction, kidney dysfunction, immune dysfunction, cardiac disease, and premature.

\section{Aim of the study}

This study is carrying out to comparative study of the effect of supplementation with some natural antioxidant extracts in restricting the renal dysfunction in rats through the following parameters:

1- Investigate of some biological evaluations. 2Antioxidants level. 3- Kidney function
4 - Histopathological examination of kidney

\section{Material and Methods}

Forty adult male Sprague - Dawley rats $(150-200$ g) allowed free access to water and standard diet (S.D.) which was prepared according to modified AIN-93-A (Reeves et al, 1993) for four days, all rats were individually weighed at the start of the experiment and housed in wire cages. The rats were divided to two groups. First group: 8 rats were fed on standard diet (S.D.), as a control group. Second group: 32 rats were injected intraperitonial with a single dose of Cis-diammine dichloride Platinum II(CDDP)for inducing renal dysfunction(nephrotoxicity) $\quad(2.5 \mathrm{mg} / \mathrm{Kg}$ body weight) was dissolved in physiological saline solution within one hour before injecting according to (Iseri et al., 2008) then it was divided to four subgroups each one contained 8 rats. (1): fed on (S.D.) nephrotoxic group. (2): fed on (S.D.) + Vitamin A (15 mg/Kg body weight/day) according to (Maria et al., 2007). (3): fed on (S.D.) + Vitamin E (317 I.U. $/ \mathrm{kg}$ body weight/day) according to (Tiu Tian et al., 2005). (4): fed on (S.D.) + Vitamin C (280 I.U. /kg body weight/day) (Tiu Tian et al., 2005).

The experimental period was four weeks.

Biological Evaluation: -Food Intake: The total diet consumed per group during the period of the experiment was calculated.

-Body Weight Gain: It was calculated as follow: Body weight gain $(\mathrm{g})=$ final weight $(\mathrm{g})$ - initial weight $(\mathrm{g})$.

-Food Efficiency Ratio (FER): It was calculated as mentioned by (Hosoya, 1980).

-Relative Organs Weight: After animal sacrificed the internal organs (heart, liver, kidney and spleen) were removed and washed in saline. Then the relative weight of organs was determined according to the method described by (Chapman et al., 1959). The kidneys were kept in $10 \%$ formalin for the histological study,described by (Janebova and Zima, 1997).

Antioxidants level:

-Determination of Serum Vitamin E concentration by HPLC according to the method described by (Janebova and Zima, 1997).

- Determination of Kidney Glutathione Content: Glutathione (GSH) was determined according to (Beutler et al., 1963). 
Kidney function :

- Determination of serum Urea Nitrogen: It was determined by urease-colorimetric method described by (Tietz, 1990).

- Determination of serum Creatinine was determined by colorimetric method with deproteinization described by (Tietz, 1986).

Histological investigation: Histological examination of kidney was carried out according to the (Drurg and Wsllington, 1980). All sections were examined in Faculty of Veterinary, Cairo Univeristy, Egypt.

Statistical analysis :The results were analyzed statistically using means and standard deviation (SD) using SPSS/PC program V17 (2008) .T-test and ANOVA were applied in this study for comparison among mean of different groups according to the method described by (Kurtz,1983)

\section{Results}

\section{Biological Evaluation Results:}

Food intake: Table (1) showed that the nephrotoxicity rats exhibited significant decrease in food intake at $(\mathrm{P}<0.01)$ compared with a control group. However, nephrotoxicity rats supplemented with vitamin A\& E exhibit non-significant decrease and nephrotoxicity rats supplemented with vitamin $\mathrm{C}$ showed a significant decrease in food intakes compared with a control group and a significant increase at $(\mathrm{P}<0.01)$ compared with nephrotoxic group.

Body Weight Gain: Concerning to the body weight gain in the nephrotoxic group, there was a significant reduction at $(\mathrm{P}<0.01)$ by when compared with a control group. Nephrotoxicity rats supplemented with vitamin A,E\& $C$ showed a highly significant reduction in $\%$ body weight gain at $(\mathrm{P}<0.01)$ compared with a control group. While comparing these groups with nephrotoxic group, there was a highly significant increase at $(\mathrm{P}<0.01)$.

Food Efficiency Ratio (FER): From table (1), it could be observed that (FER) in the nephrotoxic group showed a significant reduction at (P 0.01) when compared with a control group. On the other hand, in vitamin $\mathrm{A} \& \mathrm{C}$ supplemented group there was a highly significant decrease in (FER) at $(\mathrm{P}<$ 0.01) compared with a control group and a highly significant increase at $(\mathrm{P}<0.01)$ by comparing with nephrotoxic group. In vitamin E supplemented

group, there was a highly significant increase in $(\mathrm{FER})$ at $(\mathrm{P}<0.01)$ compared with a control group and a highly significant increase at (P 0.01) when compare with nephrotoxic group.

Organs weight: Table (2) showed that in a nephrotoxic group there was a highly significant increase in the hepato somatic, reno somatic and cardio somatic indeces at $(\mathrm{P}<0.01)$, while a significant reduce in the spleeno somatic index at $(\mathrm{P}<0.05)$ compared with a control group. The nephrotoxicity rats supplemented with vitamin A exhibited a highly significant increase in the relative weight of hepato somatic and reno somatic indeces at $(\mathrm{P}<0.01)$ by, while a significant reduction in the relative weight of spleeno somatic and cardio somatic indeces at $(\mathrm{P}<0,05)$ in compared with a control group. Comparing this group with nephrotoxic group showed a highly significant reduction in the hepato somatic, reno somatic and cardio somatic indeces at $(\mathrm{P}<0.01)$.

Concerning vitamin $\mathrm{E} \& \mathrm{C}$ treatment group, it recorded a significant increase in the hepato somatic index at $(\mathrm{P}<0.05)$, in the reno somatic index at $(\mathrm{P}<0.01)$ and a significant reduction in the spleeno somatic index at $(\mathrm{P}<0.05)$ compared with a control group. Comparing the same group with the nephrotoxic group showed a significant reduction in the hepato somatic, reno somatic and cardio somatic indeces at $(\mathrm{P}<0.01)$.

\section{Antioxidant Levels:}

\section{Serum Vitamin E and Kidney Glutathione Content:}

Data summarized in table (3) showed that nephrotoxic group exhibited a highly significantly reduction in serum vitamin $\mathrm{E}$ concentration and kidney glutathione content at $(\mathrm{P}<0.01)$ when compared with a control group.

As showed in table (3), the nephrotoxicity rats supplemented with vitamin A exhibited

a highly significant reduction in serum vitamin $E$ concentration at $(\mathrm{P}<0.01)$ and non-significant increase in kidney glutathione content when compared with a control group. Comparing this group with nephrotoxic group, there were a highly significant increase in serum vitamin $E$ concentration and kidney glutathione content at $(\mathrm{P}<0.01)$ 
As illustrated in table (3), vitamin E\& C supplemented group showed a significant decrease in serum vitamin $\mathrm{E}$ concentration at $(\mathrm{P}<0.01)$ and significantly increase in kidney glutathione content at $(\mathrm{P}<0.01)$ when compared with a control group.

While, these groups showed a highly significantly increase in serum vitamin Eat $(\mathrm{P}<0.01)$ and a highly significant increase in kidney glutathione content at $(\mathrm{P}<0.01)$ when compared with nephrotoxic group.

\section{Renal Function Results:}

Table (4) showed that serum urea nitrogen and creatinine levels in the positive control group showed a highly significant elevate at $(\mathrm{P}<0.01)$ when compared with the control group.

From the same table, nephrotoxicity rats supplemented with vitamin $\mathrm{A}, \mathrm{E} \& \mathrm{C}$ showed a significant increase in serum nitrogen and creatinine at $(\mathrm{P}<0.01)$ when compared with the control group. While, in comparing with nephrotoxic group showed a significantly reduction in serum urea nitrogen and creatinine at $(\mathrm{P}<0.01)$.

\section{Histopathological Results:}

As showed in Fig. (1) microscopically examination of kidney of rats from a control group revealed the normal histological structure of renal parenchyma. Meanwhile, as cleared in Fig. (2) Kidney of rats from nephrotoxic group showed vacuolations of epithelial lining renal tubules in the renal cortex. There was a congestion of glomerular tufts, deposition of protein cast in the bowman's space and in the lumen of renal tubules. From Fig. (3) There was presence of eosinophilic protein cast in the lumen of renal tubules as well as per tubular leucocytic cells infiltration. In addition, a cystic dilatation of renal tubules.

Data presented in table (5) and Fig. (4) Showed that $(40 \%)$ of rat's kidney from vitamin A group revealed normal renal parenchyma. While, Fig. (5) Showed that $(60 \%)$ of the same group revealed homogenous eosinophilic protein cast in the lumen of renal tubules. Moreover, $40 \%$ of this group revealed focal area of tubular necrosis associated with leucocytic inflammatory cells infiltration.

From table (5), it could be observed that $(20 \%)$ of rat's renal from vitamin $\mathrm{E}$ group showed no histopathological changes except congestion in glomerular tufts and intertubular renal blood capillaries (Fig.6). There was $40 \%$ showed protein cast in the lumen of some renal tubules and atrophy of some glomerular tufts. As showed in table (4) and Fig.(7), 80\% of the kidney of rats from vitamin E revealed a cystic dilatation of renal tubules with eosinophilic protein cast in their lumen. While, $20 \%$ of the same group showed a focal interstitial nephritis.

From the same table and Fig.(8) it could observed that $(60 \%)$ from vitamin $C$ group revealed no histopathological changes. Meanwhile, (40\%) from the same group showed presence of protein cast in the lumen of renal tubules and focal tubular necrosis associated with leucocytic inflammatory cells infiltration. Moreover, it could be noticed in (Fig. (9) that $(40 \%)$ of this group showed a hypertrophy and congestion of glomerular tuft associated with nephritis .

\section{Discussion}

\section{Biological Evaluation:}

Food intake:. The obtained results of nephrotoxic rats exhibited significant decrease in food intake. These results are in the line with (Armando et al., 2002 \& Aaron et al., 2004 ) who stated that rats injected with Puromycin Amino nucleoside to induce nephrotoxicity exhibited significant reduction in food intake at $(\mathrm{P}<0.05)$ than control group.

The present results appear to be in harmony with that of (Maneesh and Jayalekshmi, 2005) who stated that Ascorbic acid and Alphatocopherol exhibited an ability to counteract the reduction in food intake of nephrotoxicity rats.

Body Weight Gain: The present reduction in body weight gain of the nephrotoxic group was in agreement with (Armando et al., 2002 and Aaron et $\boldsymbol{a l .}$, 2004) who stated that rats injected with Puromycin Amino nucleoside inducing nephrotoxicity showed a significant reduction in body weight gain.

These results appear to be agree with that of (Maneesh and Jayalekshmi, 2005) who stated that Ascorbic acid and Alpha-tocopherol exhibited an ability to counteract the reduction in body weight gain of nephrotoxic rats. Food Efficiency Ratio (FER): The present results of FER appear to be agree with that of (Maneesh and Jayalekshmi, 2005) who stated that the Ascorbic acid and Alpha-tocopherol exhibited an ability to counteract the reduction in food efficiency ratio of nephrotoxic rats.

-Organs somatic index: The present results were agree with (Iseri et al., 2007) who cleared that 
Cisplatin which induce kidney and liver dysfunction in rats significantly increase kidney and liver weight. Also, these results are in harmony with (Saad et al., 2007) who demonstrate that Cisplatin inducing nephrotoxicity in rats, significant increase the relative weight of kidney. In addition (Stevan et al., 2002) showed that chronic administration of (PAN) for inducing nephrotoxicity in rats resulted an increase in kidney weight ( $2.1 \mathrm{~g}$ versus control $1.44 \mathrm{~g})$.

These results of organ somatic indeces appear to be in agreement with (Cravenet al., 2007) who cleared that treatment with vitamin C $(10 \mathrm{~g} / \mathrm{kg}$ b.w. /d) in the drinking water significantly reduced the kidney weight compared with untreated diabetic nephropathy rats. Beside, (Patricia et al., 2005) who indicated that kidney weight was significantly higher in all of the diabetic nephropathy groups compared with age-matched controls. Supplementation with vitamin C significantly reduced kidney weight compared with that untreated diabetic nephropathy rats. By contrast, kidney weight in rats that treatment with vitamin $\mathrm{E}$ was not different from that untreated diabetic nephropathy rats.

Antioxidant Levels:

Serum Vitamin E and Kidney Glutathione Content:

The present results were in harmony with Saad $\boldsymbol{e t}$ aL. ( 2007) who demonstrated that serum vitamin $\mathrm{E}$ and kidney glutathione content were significant reduce at $(\mathrm{P}<0.01)$ in group of rats injected with Cisplatin-inducing neophrotoxicity when compared with control group. In the same time, the results were in agreement with Duru et aL. ( 2008) who demonstrated that there were a significant reduction in serum vitamin $\mathrm{E}$ and kidney glutathione content at $(\mathrm{P}<0.05)$ in rats injected with Cyclosporine A (CSA) for inducing nephrotoxicity when compared with control group.

The results obtained were partially agree with Atasayar et aI, ( 2009) who showed that treatment with antioxidants (vitamin E and vitamin C) in nephrotoxicity rats injected by a single dose of Cisplatin prevented the decrease in kidney glutathione content.

In addition, these results partially agreed with that of (Mehri et aI., 2005) who showed that treatment with vitamin $\mathrm{C}$ didn't show a significant effect on renal tissue glutathione content of Gentamicininduced nephrotoxicity in rats. While, Vitamin E treatment prevented the GM -induced reduction in renal tissue glutathione content, also co- administration of vitamin $\mathrm{C}$ and $\mathrm{E}$ significantly prevented the GM-induced nephrotoxicity demonstrating by preservation of GSH level.

Omar et al.,(2012) cleared that Cisplatin (CP) induced decline of antioxidant enzymes and a decreased level of GSH, Vit. $\mathrm{C}$ and Vit. $\mathrm{E}$ in hepatic tissue and plasma. Treatment with Vit. C, DPPD and L-cysteine in combination with $\mathrm{CP}$ restored the content of GSH, Vit. C and Vit. E to about normal control levels.

\section{Kidney Function :}

The present study results were in the line with (Saad et al., 2007) who demonstrated that serum urea nitrogen and creatinine levels were significant increase in nephrotoxic rats when compared with control group.

These results were in agreement with Korkmaz and Kolankaya (2009) who reported that Ascorbic acid $(250 \mathrm{mg} / \mathrm{kg}$,i.p. $)$ treatment significantly reduce the serum creatinine and urea nitrogen levels at $(\mathrm{P}<0,01)$ in ischemia-reperfusion rats.

In addition, the present study results were in harmony with (Mehmet et al., 2005) who demonstrated that intraperitoneal injection of vitamin C $\quad(500 \mathrm{mg} / \mathrm{kg} \quad$ b.w. $)$ alone or in combination with vitamin A (195 mg/kg b.w.) significantly decrease the level of serum creatinine and urea nitrogen at $(\mathrm{P}<0.05)$ in rats givin lipoploysaccharide $\quad(10 \mathrm{mg} / \mathrm{kg}) \quad$ (LPS)-induced endotoxemia. As well as the results of present work are partially agreement with(Ocak et al., 2007) who stated that vitamin E (1000 mg/kg b.w.i.p.) and vitamin C (200 $\mathrm{mg} / \mathrm{dl}$ in drinking water) administration significantly decrease the blood urea nitrogen and creatinine levels increased by injection of Vancomycin for inducing nephrotoxicity in rats. Beside, Yanardag et al, (2007) showed the effect of combination of vitamin C $(250 \mathrm{mg} / \mathrm{mg} / \mathrm{kg} . b w)$, vitamin E (250 mg/kg.bw) and Sodum Selenate (0.5 $\mathrm{mg} / \mathrm{kg} . \mathrm{bw})$ on Ethanol-induced renal injury in rats. Antioxidants treatment significantly reduced blood urea nitrogen and creatinine levels when compared with untreated rats.

\section{Histopathological Results:}

The obtained results were agree with (Tarladacalisir et aL., 2008) who showed that administration of Cisplatin (5 $\mathrm{mg} / \mathrm{kg} /$ month, i.v.) plus vitamin $\mathrm{C}(8 \mathrm{mg} / \mathrm{kg} / \mathrm{day}$, i.m.) for 3 month, although the structural damages and morphometric changes were lessened, mononuclear cell infiltration was still observed. While, the study 
results partially agree with Niu $\boldsymbol{e t} \boldsymbol{a L},(\mathbf{2 0 0 5})$ who demonstrated that treatment of Dahl salt-sensitive (SS) rats on a high-sodium intake with vitamin $\mathrm{C}$ $(98 \mathrm{mg} / \mathrm{d})$ in the drinking water and vitamin $\mathrm{E}(111$ $\mathrm{IU} / \mathrm{d})$ in the food for 5 weeks significantly decreased $(\mathrm{P}<0.01)$ glomerular necrosis and renal tubulointerstitial damage.

In addition, the results of the present work were in the line with (Mehmet et al., 2005) who cleared that in endotoxemic rats treated with vit $\mathrm{C}$, the severity of degenerative changes, shrunken glomeruli and especially tubules and mononuclear cell infiltration were less than in endotoxemic untreated rats and endotoxemic rats treated with vit A. In endotoxemic rats treated with vit $\mathrm{A}$ and vit $\mathrm{C}$, degenerative changes in the tubules or glomeruli and mononuclrar cell infiltration were not observed. Beside, Korkmaz and Kolankaya, (2009) mentioned that treatment with Ascorbic Acid reversed the histopathological alterations normally induced by ischemia/reperfusion (I/R). In addition, Ocak et al., (2007) demonstrated that vitamin E
$(1000 \mathrm{mg} / \mathrm{kg}$ i.m. $)$ and $\mathrm{C}(200 \mathrm{mg} / \mathrm{dl}$ in drinking water) were the most beneficial agent on Vancomycin-induced tubular damage.

In addition, the results of present work were in agreement with (Mehmet et al, 2005) who cleared that in endotoxemic rats treated with vit $\mathrm{C}$, the severity of degenerative changes, shrunken glomeruli and especially tubules and mononuclear cell infiltration were less than in endotoxemic untreated rats and endotoxemic rats treated with vit A. In endotoxemic rats treated with vit $\mathrm{A}$ and vit $\mathrm{C}$, degenerative changes in the tubules or glomeruli and mononuclear cell infiltration were not observed.

Beside, Korkmaz and Kolankaya, (2009) mentioned that treatment with Ascorbic Acid reversed the histopathological alterations normally induced by ischemia/reperfusion (I/R). In addition, Ocak et al, (2007) demonstrated that vitamin E $(1000 \mathrm{mg} / \mathrm{kg}$ i.m.) and C $(200 \mathrm{mg} / \mathrm{dl}$ in drinking water) were the most beneficial agent on Vancomycin-induced tubular damage. 
Hewaida A.E.Fadel... et al

TABLE (1): Effect of supplementation with Vitamin A, E, and C on Food intake, Body weight Gain and Food Efficiency Ratio in Nephrotoxicity Rats.

\begin{tabular}{|c|c|c|c|c|c|c|}
\hline \multicolumn{2}{|c|}{ parameters } & CONTROL & Nephropathy & V.A & V.E & V.C \\
\hline \multirow{6}{*}{ 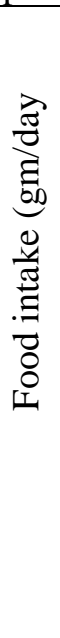 } & Mean & 9.36 & 7.21 & 9.30 & 9.33 & 8.6 \\
\hline & $\pm \mathrm{SD}$ & 0.11 & 0.11 & 0.20 & 0.07 & 0.09 \\
\hline & $\begin{array}{l}\text { \% change } \\
\text { from } \\
\text { control }\end{array}$ & - & -22.98 & -0.66 & -0.28 & -8.16 \\
\hline & P. value & - & $* *$ & N.S & N.S & $* *$ \\
\hline & $\begin{array}{l}\% \text { change } \\
\text { from } \\
\text { nephropathy }\end{array}$ & - & - & 28.97 & 29.48 & 19.23 \\
\hline & P. value & - & - & $* *$ & $* *$ & $* *$ \\
\hline \multirow{6}{*}{ 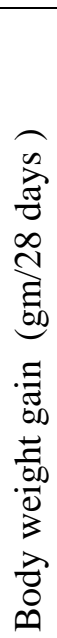 } & Mean & 18.25 & 1.27 & 12.37 & 21.87 & 6.5 \\
\hline & $\pm \mathrm{SD}$ & 0.70 & 0.07 & 0.51 & 0.64 & 0.75 \\
\hline & $\begin{array}{l}\text { \% change } \\
\text { from } \\
\text { control }\end{array}$ & - & -93.01 & -32.19 & 19.86 & -64.38 \\
\hline & P. value & - & $* *$ & $* *$ & $* *$ & $* *$ \\
\hline & $\begin{array}{l}\% \text { change } \\
\text { from } \\
\text { nephropathy }\end{array}$ & - & - & 874.01 & 1615.6 & 409.80 \\
\hline & P. value & - & - & $* *$ & $* *$ & $* *$ \\
\hline \multirow{6}{*}{ 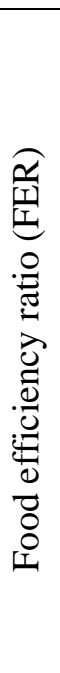 } & Mean & 0.06 & 0.006 & 0.04 & 0.08 & 0.02 \\
\hline & $\pm \mathrm{SD}$ & 0.003 & 0.0003 & 0.001 & 0.002 & 0.002 \\
\hline & $\begin{array}{l}\text { \% change } \\
\text { from } \\
\text { control }\end{array}$ & - & -90.92 & -31.73 & 20.20 & -61.24 \\
\hline & P. value & - & $* *$ & $* *$ & $* *$ & $* *$ \\
\hline & $\begin{array}{l}\% \text { change } \\
\text { from } \\
\text { nephropathy }\end{array}$ & - & - & 652.56 & 1225.2 & 327.31 \\
\hline & P. value & - & - & $* *$ & $* *$ & $* *$ \\
\hline
\end{tabular}

- Values are statistically significant at $* \mathrm{P}<0.05, * * \mathrm{P}<0.01$, (N.S) Non-Significant. 
Comparative studies....

TABLE (2): Effect of supplementation with Vitamin A, E, and C on The Organs somatic indeces in Nephrotoxicity Rats.

\begin{tabular}{|c|c|c|c|c|c|c|}
\hline \multicolumn{2}{|c|}{ Groups } & control & Nephropathy & V.A & V.E & V.C \\
\hline \multirow{6}{*}{ 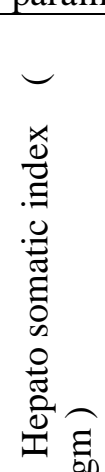 } & Mean & 3.37 & 4.02 & 3.71 & 3.49 & 3.52 \\
\hline & $\pm \mathrm{SD}$ & 0.11 & 0.07 & 0.06 & 0.06 & 0.07 \\
\hline & $\begin{array}{l}\% \text { change } \\
\text { from } \\
\text { contror }\end{array}$ & - & 19.28 & 10.18 & 3.51 & 4.43 \\
\hline & P. value & - & $* *$ & $* *$ & $*$ & $* *$ \\
\hline & $\begin{array}{l}\% \text { change } \\
\text { from } \\
\text { Nephropathy }\end{array}$ & - & - & -7.63 & -13.22 & -12.44 \\
\hline & P. value & - & - & $* *$ & $* *$ & $* *$ \\
\hline \multirow{6}{*}{ 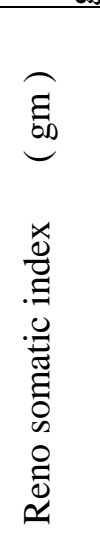 } & Mean & 0.95 & 1.46 & 1.04 & 1.06 & 0.94 \\
\hline & $\pm \mathrm{SD}$ & 0.04 & 0.06 & 0.02 & 0.03 & 0.02 \\
\hline & $\begin{array}{l}\% \text { change } \\
\text { from } \\
\text { control }\end{array}$ & - & 53.68 & 9.32 & 11.20 & -0.81 \\
\hline & P. value & - & $* *$ & $* *$ & $* *$ & N.S \\
\hline & $\begin{array}{l}\% \text { change } \\
\text { from } \\
\text { Nephropathy }\end{array}$ & - & - & -28.86 & -27.63 & -35.46 \\
\hline & P. value & - & - & $* *$ & $* *$ & $* *$ \\
\hline \multirow{6}{*}{ 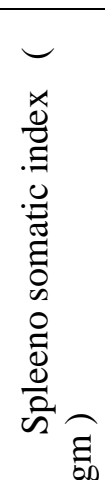 } & Mean & 0.64 & 0.60 & 0.61 & 0.60 & 0.62 \\
\hline & $\pm \mathrm{SD}$ & 0.02 & 0.02 & 0.01 & 0.03 & 0.01 \\
\hline & $\begin{array}{l}\% \text { change } \\
\text { from } \\
\text { control }\end{array}$ & - & -6.06 & -4.18 & -5.15 & -2.85 \\
\hline & P. value & - & * & * & N.S & N.S \\
\hline & $\begin{array}{l}\% \text { change } \\
\text { from } \\
\text { Nephropathy }\end{array}$ & - & - & 1.99 & 0.96 & 3.41 \\
\hline & P. value & - & - & $* *$ & $* *$ & $* *$ \\
\hline \multirow{6}{*}{ 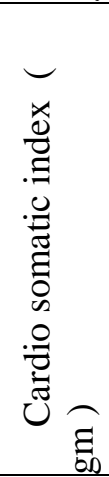 } & Mean & 0.30 & 0.33 & $0 . .29$ & 0.29 & 0.30 \\
\hline & $\pm \mathrm{SD}$ & 0.01 & 0.01 & 0.004 & 0.01 & 0.004 \\
\hline & $\begin{array}{l}\% \text { change } \\
\text { from } \\
\text { control }\end{array}$ & - & 11.06 & -4.63 & -5.15 & -0.61 \\
\hline & P. value & - & $* *$ & * & N.S & N.S \\
\hline & $\begin{array}{l}\% \text { change } \\
\text { from } \\
\text { Nephropathy }\end{array}$ & - & - & -14.11 & -14.58 & -10.49 \\
\hline & P. value & - & - & $* *$ & $* *$ & $* *$ \\
\hline
\end{tabular}

- Values are statistically significant at $* \mathrm{P}<0.05, * * \mathrm{P}<0.01$, (N.S) Non-Significant. 
TABLE (3): Effect of supplementation with Vitamin A, E, and C on Serum Vitamin E Concentration and Kidney Glutathione Content in Nephrotoxicity Rats.

\begin{tabular}{|c|c|c|c|c|c|c|}
\hline \multicolumn{2}{|c|}{ parameters } & control & nephropathy & V.A & V.E & V.C \\
\hline \multirow{6}{*}{ 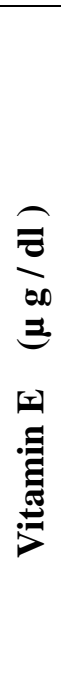 } & Mean & 501.25 & 371.62 & 406.37 & 475.5 & 422.62 \\
\hline & $\pm \mathrm{SD}$ & 3.53 & 2.5 & 6.92 & 1.85 & 3.42 \\
\hline & $\begin{array}{l}\text { \% change } \\
\text { from } \\
\text { control }\end{array}$ & - & -25.81 & -18.87 & -5.08 & -15.63 \\
\hline & P. value & - & $* *$ & $* *$ & $* *$ & $* *$ \\
\hline & $\begin{array}{l}\text { \% change } \\
\text { from } \\
\text { Nephropathy }\end{array}$ & - & - & 9.35 & 27.95 & 13.72 \\
\hline & P. value & - & - & $* *$ & $* *$ & $* *$ \\
\hline \multirow{6}{*}{ 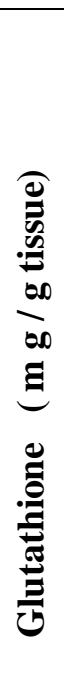 } & Mean & 14.60 & 10.21 & 15.11 & 22.13 & 15.91 \\
\hline & $\pm \mathrm{SD}$ & 0.99 & 0.32 & 1.04 & 1.77 & 1.14 \\
\hline & $\begin{array}{l}\text { \% change } \\
\text { from } \\
\text { control }\end{array}$ & - & -30.04 & 3.52 & 51.57 & 9.003 \\
\hline & P. value & - & $* *$ & N.S & $* *$ & $*$ \\
\hline & $\begin{array}{l}\text { \% change } \\
\text { from } \\
\text { Nephropathy }\end{array}$ & - & - & 47.98 & 116.66 & 55.81 \\
\hline & P. value & - & - & $* *$ & $* *$ & $* *$ \\
\hline
\end{tabular}

Values are statistically significant at $* \mathrm{P}<0.05, * * \mathrm{P}<0.01$, (N.S) Non-Significant. 
Comparative studies....

TABLE (4): Effect of supplementation with Vitamin A, E, and C on Serum Urea Nitrogen and Creatinine in Nephrotoxicity Rats.

\begin{tabular}{|c|c|c|c|c|c|c|c|}
\hline \multicolumn{3}{|c|}{$\begin{array}{c}\text { Groups } \\
\text { parameters }\end{array}$} & Control & Nephropathy & V.A & V.E & V.C \\
\hline \multirow{6}{*}{ 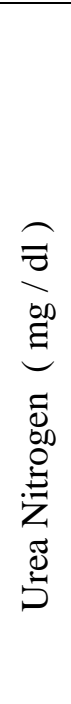 } & $\begin{array}{l}\text { Ref } \\
\text { Range }\end{array}$ & Mean & 26.51 & 69.68 & 36.22 & 32.9 & 29.96 \\
\hline & \multirow{5}{*}{ 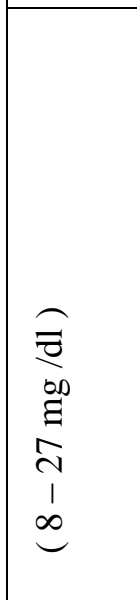 } & $\pm \mathrm{SD}$ & 0.88 & 0.72 & 0.87 & 0.82 & 1.17 \\
\hline & & $\begin{array}{l}\% \text { change } \\
\text { from } \\
\text { control }\end{array}$ & - & 162.84 & 36.63 & 24.09 & 13.01 \\
\hline & & P. value & - & $* *$ & $* *$ & $* *$ & $* *$ \\
\hline & & $\begin{array}{l}\text { \% change } \\
\text { from } \\
\text { Nephropathy }\end{array}$ & - & - & -48.01 & -52.78 & -48.50 \\
\hline & & P. value & - & - & $* *$ & $* *$ & $* *$ \\
\hline \multirow{6}{*}{ 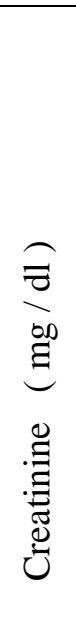 } & \multirow{6}{*}{ 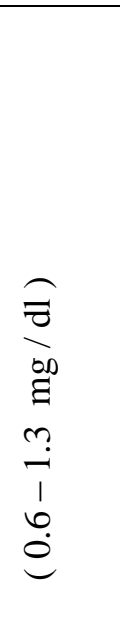 } & Mean & 0.64 & 2.05 & 0.91 & 0.81 & 0.75 \\
\hline & & $\pm \mathrm{SD}$ & 0.01 & 0.14 & 0.02 & 0.03 & 0.06 \\
\hline & & $\begin{array}{l}\% \text { change } \\
\text { from } \\
\text { Control }\end{array}$ & - & 217.21 & 41.97 & 25.72 & 17.21 \\
\hline & & P. value & - & $* *$ & $* *$ & $* *$ & $* *$ \\
\hline & & $\begin{array}{l}\text { \% change } \\
\text { from } \\
\text { Nephropathy }\end{array}$ & - & - & -55.25 & -60.36 & -63.04 \\
\hline & & P. value & - & - & $* *$ & $* *$ & $* *$ \\
\hline
\end{tabular}

Values are statistically significant at $* \mathrm{P}<0.05, * * \mathrm{P}<0.01$. 
Hewaida A.E.Fadel... et al

TABLE (5): Effect of supplementation with Vitamin A, E, and C on kidney histopathological in nephrotoxicity rats

\begin{tabular}{|c|c|c|c|c|c|c|c|c|c|c|}
\hline \multirow{2}{*}{ Parameters } & \multicolumn{2}{|c|}{ control } & \multicolumn{2}{|c|}{ Nephropathy } & \multicolumn{2}{|c|}{ V.A } & \multicolumn{2}{|c|}{ V.E } & \multicolumn{2}{|c|}{ V.C } \\
\hline & $\mathbf{N}$ & $\%$ & $\mathbf{N}$ & $\%$ & $\mathrm{~N}$ & $\%$ & $\mathrm{~N}$ & $\%$ & $\mathrm{~N}$ & $\%$ \\
\hline $\begin{array}{l}\text { Normal } \\
\text { histological } \\
\text { structure of renal } \\
\text { parenchyma. }\end{array}$ & $5 / 5$ & 100 & - & - & $2 / 5$ & 40 & - & - & $3 / 5$ & 60 \\
\hline $\begin{array}{l}\text { Vacuolations of } \\
\text { epithelial lining } \\
\text { renal tubules in } \\
\text { the renal cortex. }\end{array}$ & - & - & $5 / 5$ & 100 & - & - & - & - & - & - \\
\hline $\begin{array}{l}\text { Congestion of } \\
\text { glomerular tufts }\end{array}$ & - & - & $5 / 5$ & 100 & - & - & $1 / 5$ & 20 & $2 / 5$ & 40 \\
\hline $\begin{array}{l}\text { Deposition of } \\
\text { protein cast in } \\
\text { the Bowman's } \\
\text { space and in the } \\
\text { Lumen of the } \\
\text { renal tubules. }\end{array}$ & - & - & $5 / 5$ & 100 & - & - & - & - & - & - \\
\hline $\begin{array}{l}\text { Presence of } \\
\text { Eosinophilic } \\
\text { protein cast in } \\
\text { the Lumen of } \\
\text { renal tubules as } \\
\text { well as } \\
\text { peritubular } \\
\text { leucocytic cell } \\
\text { infiltration }\end{array}$ & - & - & $5 / 5$ & 100 & $3 / 5$ & 60 & $4 / 5$ & 80 & $2 / 5$ & 40 \\
\hline $\begin{array}{l}\text { Cystic dilatation } \\
\text { of renal tubules. }\end{array}$ & - & - & $5 / 5$ & 100 & - & - & $4 / 5$ & 80 & - & - \\
\hline $\begin{array}{l}\text { Focal area of } \\
\text { tubular necrosis } \\
\text { associated with } \\
\text { leucocytic } \\
\text { inflammatory } \\
\text { cells infiltration. }\end{array}$ & - & - & - & - & $2 / 5$ & 40 & - & - & $2 / 5$ & 40 \\
\hline $\begin{array}{l}\text { Focal interstitial } \\
\text { nephritis }\end{array}$ & - & - & - & - & - & - & $1 / 5$ & 20 & - & - \\
\hline $\begin{array}{l}\text { Congestion } \\
\text { intertubular } \\
\text { renal blood } \\
\text { capillaries. }\end{array}$ & - & - & - & - & - & - & $1 / 5$ & 20 & - & - \\
\hline
\end{tabular}




\section{Comparative studies....}

Fig. (1): Kidney of rat from negative control group showing the normal histological structure of renal parenchyma.

Fig. (2): Kidney of rat from positive control group showing vacuolations of epithelial lining renal tubules in the renal cortex.

Fig. (3): Kidney of rat from positive control group showing presence of eosinophilic protein cast in the lumen of renal tubules and peritubular leucocytic cell infiltration. 
Hewaida A.E.Fadel... et al

Fig.(4): Kidney of rat from vitamin A group showing apparent normal renal parenchyma.

Fig. (5): Kidney of rat from vitamin A group showing homogenous eosinophilic protein cast in the lumn of renal tubules. 


\section{Comparative studies....}

Fig.(6): Kidney of rat from vitamin E group showing congestion of glomerular tuft and intertubular renal blood capillaries

Fig.(7): Kidney of rat from vitamin E group showing cystic diltation of renal tubules with eosinophilic protein cast in their lumen.

Fig.(8): Kidney of rat from vitamin C group showing no histopathological changes. 
Fig.(9): Kidney of rat from vitamin C group showing hypertrophy and congestion of glomerular tuft associated with nephritis.

\section{References}

Aaron E, Gary F, Chery S, Kevin E, Jean L O and Chris B. (2004):

Protection Against Puromycin Amino Nucleoside Induced Chronic Renal Disease In The WistarFurth Rat. Am. J. Physiol. Renal Physiol. March. 287: F81-F89.

Armando R, Fernanda M, Cristino C, Rogelio H, Carlos A, Jose P, Ricardo C and Nimbe T. (2002): A Soy Protein Diet Alters Hepatic Lipid Metabolism Gene Expression And Reduces Serum Lipids And Renal Fibrogenic Cytokines In Rats With Chronic Nephrotic Syndrome. The American Society For Nutritional Sciences J.

Nutr. Sep.132: 2562-2569.

Atasayar S, Gurer H, Orhan H, Gurel B, Girgin G and Ozgunes H. (2009):

Preventive Effect of Aminoguanidine Comared To Vitamin

E and C On Cisplatin-Induced Nephrotoxicity In Rats. Exp .

Toxicol. Pathol. Jan. 61(1): 23-32.

Beutler E, Duron O, and Kelly B M. (1963): Improved method for the determination of blood glutathione. J. Lab. Clin. Med., 61: 882-888. |

Bjelakovic G. (2007): Mortality In Randomized Trials Of Antioxidant.

Supplements For Primary And Secondary Prevention:

Systematic Review And Meta- Analysis. J. AMA, 297 (8):

842-57.

Bruce M C. (2004): Human Embryology And Developmental Biology. Third Edition. Saint Louis. Mosby Elsevier
Chapman D G, Castilla R and Campbell J A. (1959): Evaluation Of Pro ten In Food. IA Method For The Determination Of Protein Efficiency Ratio. Can. J. Biochem. Phsiol. 676-686

Craven PA, Derubertis F R, Kagan V E, Melhem M and Stuer R K. (2007):

Effects of Supplementation With Vitamin C Or E On Albuminuria, Glomerulr TGF-beta And Glomerular Size In Diabetes. J. Am. Soc. Nephrol. Sep.8 (9):1405-14.

Drury R AV and Wallington E A. (1980): Carltons Histological Techniques Oxford University Press, New York. Pronto. P: 206:225.

Duru M, Nacar A, Yonden Z, Kuvandik M R, Koc A, Akaydin Y, Oksuz H and Sogut S. (2008):. Protective Effect OfN-acetylcysteine On Cyclosporine A-Induced Nephrotoxicity. Ren. Fail. 30(4): 453-9.

Hosoya N . (1980): Nutrition Experiments Using Small Animals. Tokyo: Daiichi Shuppan. Japanese. P.71.

Iseri S, Ercan F, Gedik N, Yuksel $M$ and Alican T. (2008): Simvastatin Attenuates Cisplatin Induced Kidney And Liver Damage In Rats. Toxicology. May 21. 247(2-3):161

Janebova $M$ and Zima T. (1997): Methods For Determination Of Vitamins A and E Our Simple HPLC Assay. Sbomik Lekarsky., 98(3):195-208

Kurtz N R (1983): Introduction to Social Statistics.Mc Grow-Hill Book Company. New York. P.163.

Maneesh M and Jayalekshmi H . (2005): Effect Of Ascorbic Acid, Alpha-Tocopherol, Lecithin And Laspartate On Ethanol Induced Hypoproteinemia And Hyperlipidemia In Rats. Indian. J. Physiol. Pharmacol. Oct- Dec. 49 (4): 422-6. Maria M E, Elisa C, Ana M, David S Z, DavId S . Guillermo P L, Javier L C, Francisco S M, Mana L G B and Francisco M M (2007): Therapeutic Effect of All-Trans-Retinoic Acid (AT-RA) On An Autoimmune Nephritis Experimental 
Model: Rol of The VLA-4 Integrin. BMC Nephrol. January. 24: 8-13.

Mehri K, Hossein K, Mahdieh F, Rana G and Maryam Z. (2005): Effect of Co-Supplementation Of Vitamins $\mathrm{E}$ and $\mathrm{C}$ On Gent micin-Induced Nephrotoxicity In Rat. Department Of PhyslOlogy. Faculty Of Medicine. Tahran University of Medical Sciences. Tahran. Iran.

Mohamadin A M, EI-Beshbishy $\mathrm{H}$ A and EI-Mahdy M A - (2005): Green Tea Extract Attenuates Cyclosporine A-Induced Oxidative Stress In Rats. Pharmacol. Res. 5 Jan.51 (1): 51-7.

Mehmet K, Orner C, Ferah A, Yesim H and Gulnur K (2005): Protective Effect Of Vitamin C, Alone or In Combination With Vitamin A on EndotoxinInduced Oxidative Renal Tissue Damage In Rats. Tohoku. J. Exp. Med. 206:155-162

Niu Tian Kristina D, Paul D, Michael D, Davis J R. (2005): Antioxidant Treatment Prevents Renal Damage And Dysfunction and Reduces Arterial Pressure in Salt-Sensitive Hypertension. Hypertension. 45: 934939.

Ocak S, Gorur S, Hakverdi S, Celik S and Erdogan S. (2007): Protective Effect Of Caffeic Acid Phenethyl Ester, Vitamin C,Vitamin E And NAcetylcysteine On Vancomycin-Induced Nephrotoxicity in Rats. Basic Clin. Pharmacol. Toxicol. May. 100 (5): 328-33.

Omar H M , Ahmed E A , Abdel-Ghafar S, Mohammed Sand Nasser A Y. (2012):

Hepatoprotictive effects of vitamin C, DPPD and Lcystiene against cisplatin-induced oxidative stress in male rats.J.of Biology and Earth Sciences. 2,No 1.

Patricia A, Frederick R, Valerian E, Mona $M$ and Rebecca K . (2005):

Effect Of Supplementation With Vitamin C or E On Albuminuria, Glomerular TGF And Glomerular Slze In Diabetes. J. Am. Soc. Nephrol. Sep.8 (9): 1450-5.

PerazelIa M A and Khan S. (2006):Increased Mortality In Chronic Kidney Disease: A Call to Action. Am. J. Med. Sci. 331 (3):150-3.

Reeves P G, Nielsen F H and Fahey G C. (1993): Ain-93 Punfied Diet or Laboratory Rodents: Final
Report Of The. Amencan Institute Of Nutrition. Ad Hoc Writing. Committee On The Reformulation Of The Ain76-A Rodent Diet. 1. Nutr. 123:1939-1951

Saad S Y, Arafah M M and Najjar T A.(2007): Effect Of Mycophenolate Mofetil On Cisplatin-Induced Renal Dysfunction in Rats. Cancer Chemother Phermacol. Mar. 59(4): 455-60.

Sarah LW, Steven J C, Stephen J, Jeremy R C H and Alan C. (2008):

WHO. Programs And Projects. Bulletin Of The World Health Organization. 86 (3), March. 161-240.

Saravanan N and Nalini N . (2007): Impact Of Hemidesmus Indicus R.Br. Extract On EthanolMediated Oxidative Damage In Rat Kidney. Redox. Rep. 12 (5): 229-35.

Shubhangini AJ. (2001):Nutrition and Dietetics. Ninth Reprint Premlila Vithaldas Polytechnic (Bombay). Tata Mc Graw-Hill Publishing Company Limited. New Delhi. Staci Nix MS RD. (2005): Basic Nutrition Diet Therapy. Twelfth Edition. Elsevier Mosby, Inc. USA

Stevan P,Raghvendra D, Eman $M$ and Edwin $K$. (2002): 2- Hydroxyestadiol Attenuates Renal Disease in Chronic Puromycin Aminonucleoside Nephropathy. 1. Am. Soc. Nephrol.13:2737 -2747.

Tarladacalisir Y T, Kanter M and Uygun M. (2008): Protective effects of Vitamin C On cisplatin-Induced Renal Damage: A Light and Electron microscopic Study. Ren. Fail. 30(1): 1-8.

Tietz N W.(1990): Clinical Guide To Laboratory Tests. 2ND ED.Philadelphia. WB Saunders. 566.

Tietz N W. (1986): Textbook of Clinical Chemistry. WB Saunders, Philadelphia, pp1271-1281.

Tiu Tian, Kristian D T, Paul D G ,Michael D H and Vavids M . (2005):

Antioxidant Treatment Prevents Renal Damage and Dysfunction And Reduces Arterial Pressure In SaltSensitive Hypertention. Hypertension 45 :934-939.

Yanardag R, Ozsoy 0, Ozdil S and Bolkent S. (2007): Combined Effects Of Vitamin C, Vitamin E And Sodium Selenate Supplementation On Absolute EthanolInduced Injury in Various Organs of Rats. IntJ.Toxicoi. Nov-Dec.26 (6): 513-23. 


\section{دراسات مقارنة على تأثير بعض مضادات الأكسدة الطبيعية فى الحد من الخلل الوظيفى بكلى الجرذان}

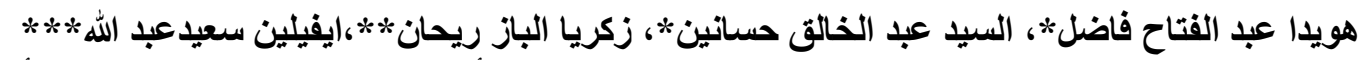

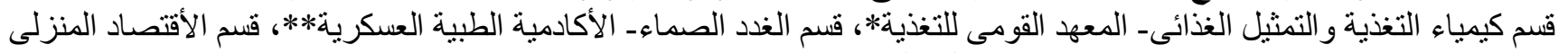

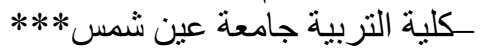

الخلاصة تهدف هذه الدراسة الى مقارنة تأثير بعض مضادات الأكسدة المستخلصة من مصادر طبيعية فى الحد من الخلل الوظيفى بكلى الجرذان

خطوات الدراسة : أجريت الدر اسة على 40جرذ ( ذكور ) من نوع الأليينو سلالة سبراجيو داولى ( 150 - 200 جما جم ). تم

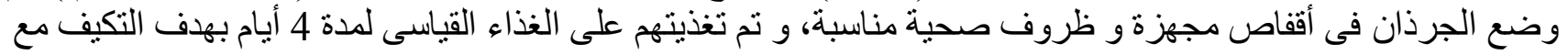

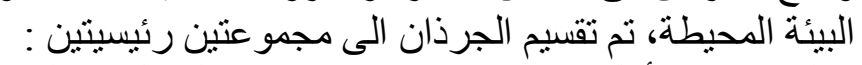

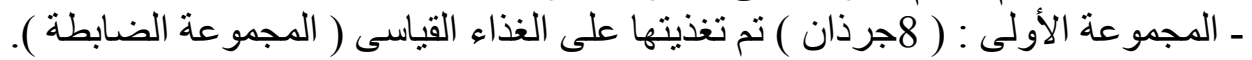

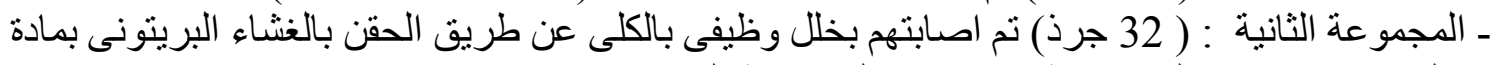

ملجم/ كم من وزن الجسم )، ثم تقسيم هذة المجموعة الى

$$
\text { مجمو عات فرعية ،يحتوى كل منها على ( } 8 \text { جرذان ) كما يلى : }
$$

1- مجمو عة تم تغذيتها على الغذاء القياسي ( المجمو عة المصابة بخلل وظيفى بالكلى).

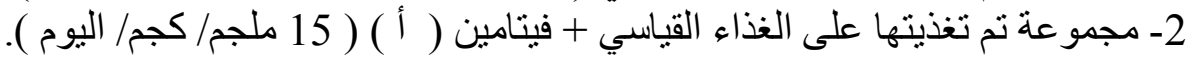

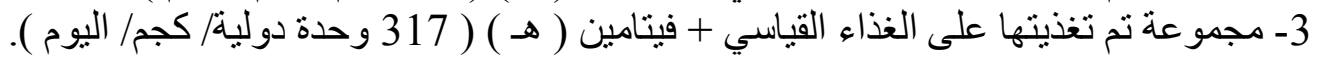

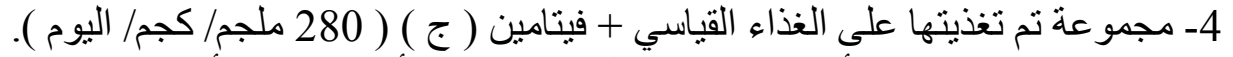

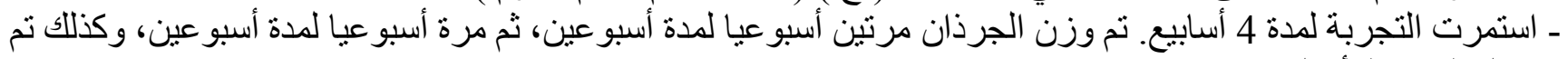
تسجيل الغذاء المأكول يوميا.

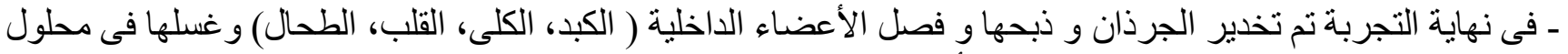

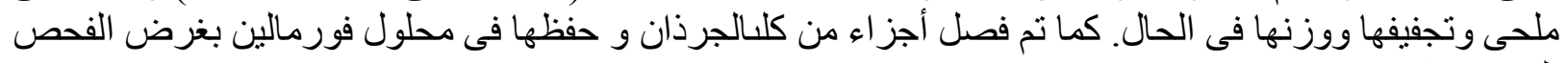

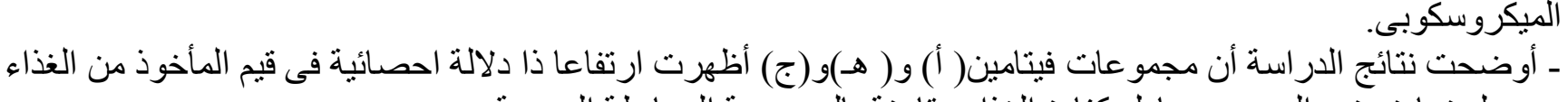

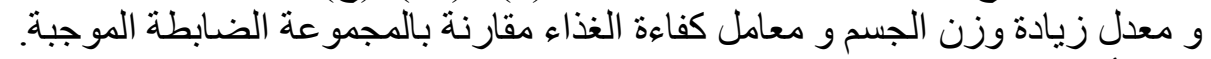

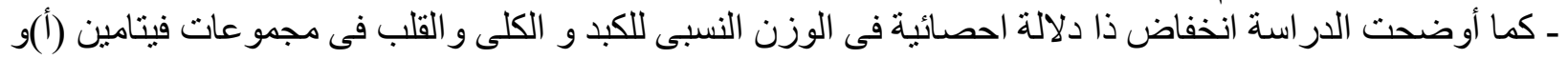

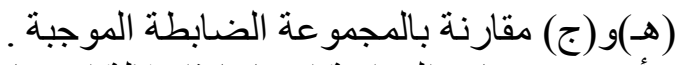
ـ أوضحت نتائج الدراسة ارتفاعا ذا دلالة الحصائية فى مستوى فيتامين هـ فى السيرم وجلوتاثيون الكبد فى مجموعات

ـ كما أوضحت أيضا انخفاض ذا دلالة احصائية فى وظائف الكلى فى مجمو عات فيتامين(أ)و (هـ)و (ج).

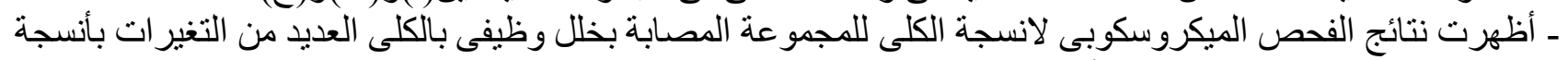

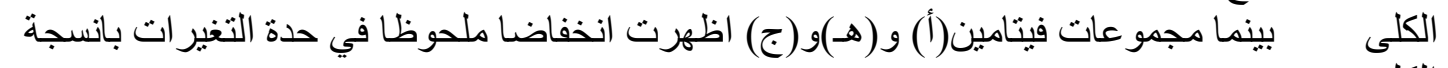

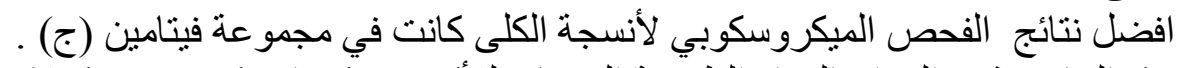

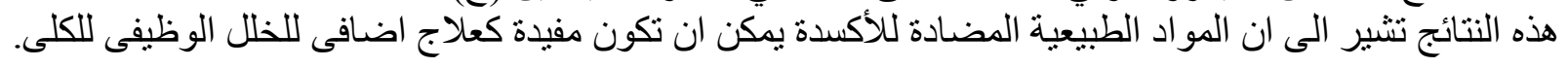

